\title{
A McGill Update of Osler's Bedside Books List
}

\author{
Andrei Liveanu*
}

Dr Murray ends his article by asking medical students to create a contemporary version of Osler's bedside books for medical students. All current medical students at McGill University were therefore invited to suggest written works that they felt every medical student should read to help them in their development as future physicians. Despite the wide diversity in backgrounds of today's medical students, and despite the somewhat unenthusiastic response rate, some interesting trends can be found. (Table 1)

As Dr Murray predicted, students suggested a number of works written by physicians. Perhaps students gravitate toward these books so that they know what lies ahead for them. House of God by Samuel Shem, a novel portraying the demanding life of medical residents was nominated by multiple students. Also popular were works in which one or more of the main characters are physicians: suggestions included Middlemarch by George Elliot and The Cider House Rules by John Irving.

Works that portrayed physicians in a negative way were particularly popular: students seem to want to be reminded how not to act as physicians. The charlatan physician in Moliere's Le Malade Imaginaire or the uncompassionate doctors in Margaret Edson's Wit serve as cautionary examples.

The search for ethics and a clear moral code is a second theme that emerges from the survey. Although no two works were suggested twice, examples included War Against the Weak: Eugenics and America's Campaign to Create a Master Race by Edwin Black and Doing Right (A Practical Guide to Ethics for Medical Trainees and Physicians) by Philip C. Hebert. Interestingly, students seemed concerned not only with ethical issues as they relate directly to their work as doctors-in-training, but also as citizens of the world.

*To whom correspondence should be addressed:

Andrei Liveanu

39 Roxton $\mathrm{Cr}$

Montreal West, QC

H4X1C7

Email: andrei.liveanu@mail.mcgill.ca
Students nominated a number of works that deal with larger issues of their generation, such as Wealth: Economics for a Crowded Planet by Jeffrey Sachs and The Shock Doctrine by Naomi Klein.

Psychiatry-related books were a third genre popular among student's suggestions. These proposed books included Truman Capote's In Cold Blood and Maxime Chattam's L'Ame du mal, both literary-style studies of the psychology of serial killers, and Veronika Decides to Die by Paolo Coelho, a novel about a teenager who attempts suicide. Through these books, medical students are possibly hoping to prepare themselves to deal with some of the most difficult patients they will encounter.

Among the rest of the suggested books is a mixture of works, ranging from 1984 to the Harry Potter series to

National Geographic Magazine.

In short, the results of this informal survey were:

- A work about physicians, whether they are portrayed positively or negatively

- A work about ethics, whether medically-related or not

- A work about psychology

- Any of a wide range of light reading

So how does this list compare to Osler's? He too suggested a book about a physician (Religio Medici), a book of morals (the Bible), and a number of general interest works (Shakespeare, Don Quixote). However, while Osler's list contains many works about philosophy, there were none to be found in the contemporary list. And while students suggested many psychiatry/psychology books, none are found on Osler's list.

This informal survey of McGill medicine students is but one more attempt at updating Osler's bedside library list. Yet this list is unique in that it asked current medical students to suggest books for their peers. Not surprisingly, a wide range of works were suggested, but despite the low number of responses, some works were suggested more than once, and many works within a same general theme were suggested. The list therefore points to a degree of agreement among medical students 
as what they ought to be reading beside their medical textbooks. Additionally, this list offers a glimpse into what students think lies ahead for them, and what they think will help them face those challenges.

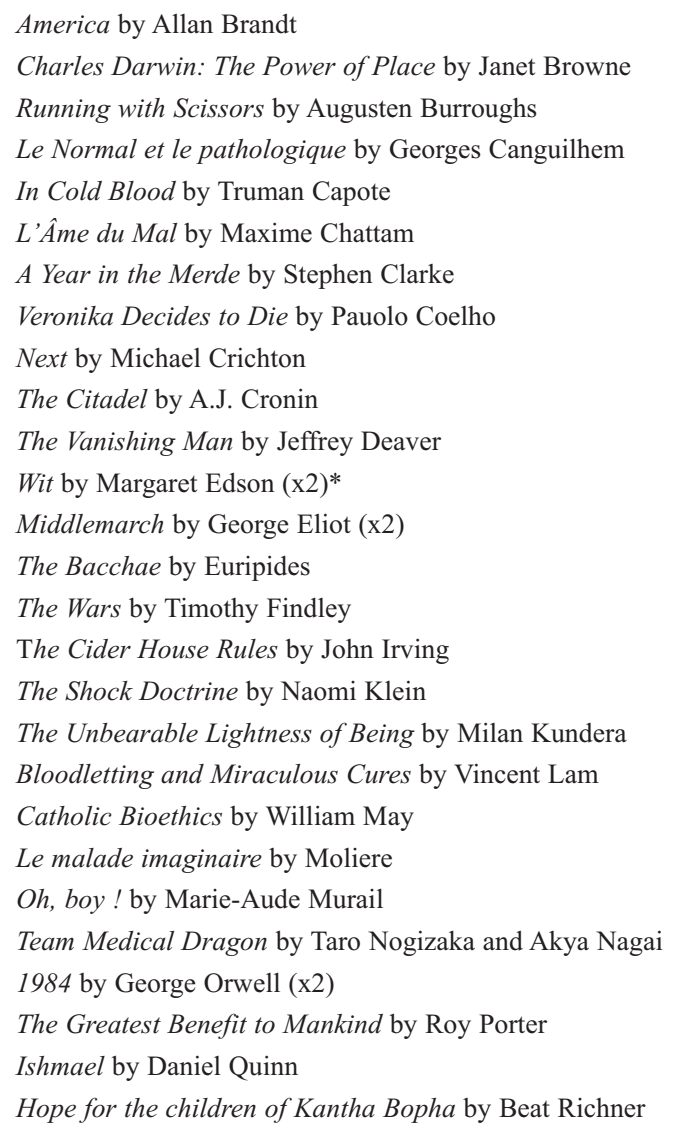

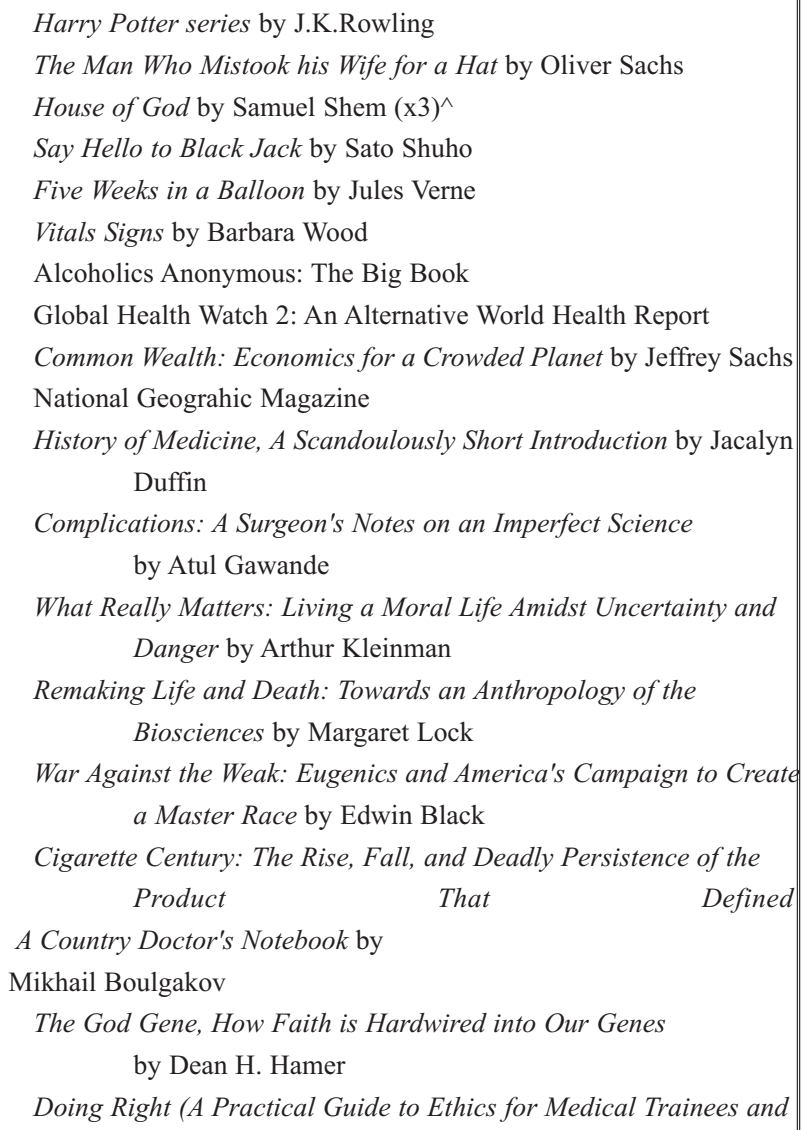

Table 1: Results of the survey: A list of all the suggestions put forward by students for a contemporary bedside reading list.

* Work suggested by two different students.

$\wedge$ Work suggested by three different students.

Andrei Liveanu (M.D.C.M., 2011) received his BSc in Microbiology and Immunology from McGill University. He is currently a medical student at McGill and the Executive Crossroads Editor for the McGill Journal of Medicine. 